\title{
Experimental studies of Ambient Cured Geopolymer Concrete
}

\author{
Xerses N. Irani ${ }^{1}$, Dr Suresh G. Patil ${ }^{2}$, Rampanth ${ }^{3}$ \\ ${ }^{2}$ (M.Tech Student, Department of Civil Engineering ,Poojya Doddappa Appa College of Engineering, \\ Kalaburagi ,affiliated to VTU Belagavi ,India \\ ${ }^{I}$ (Professor and Head of Department of Civil Engineering ,Poojya Doddappa Appa College of Engineering, \\ Kalaburagi , affiliated to VTU Belagavi, India \\ ${ }_{3}^{3}$ Research Scholar, Department of Civil Engineering ,Poojya Doddappa Appa College of Engineering, \\ Kalaburagi ,affiliated to VTU Belagavi ,India
}

\begin{abstract}
The objectives of the present work is to finalize the parameters such as Amount of binder used, Molarity of NaOH, Ratio of $\mathrm{Na}_{2} \mathrm{SiO}_{3} / \mathrm{NaOH}$ and Ratio of Liquid to Binder In the présent work, experimental investigations were performed such as compressive strength test on the ambient cured geopolymer concrete. By trial casting geopolymer concrete paramètres were finalized such as binder (Fly Ash : GGBS)as (40:60), molarity content as $8 \mathrm{M}$, Ratio of $\mathrm{Na}_{2} \mathrm{SiO}_{3} / \mathrm{NaOH}$ of 1.5 and Ratio of Liquid to binder of 0.5. . The tests were conducted for Geopolymer Concrete spécimens at diffèrent curing âges of (1, 3 and 7 days). The results of compressive strength of Binder ratio of (fly ash: GGBS) of (40:60), Molarity of $\mathrm{NaOH}$ of $8 \mathrm{M}$, Ratio of $\mathrm{Na}_{2} \mathrm{SiO}_{3} / \mathrm{NaOH}$ of 1.5 and Ratio of Liquid to binder of,0.5 gave a higher results of $24 \mathrm{~N} / \mathrm{mm}^{2}, 40 \mathrm{~N} / \mathrm{mm}^{2} 60$ $\mathrm{N} / \mathrm{mm}^{2}$ for 1,3 and 7 days respectively.
\end{abstract}

Keywords: Compressive strength.

\section{Introduction}

The fact that the production of cement adds to the pollution of environment is well known to civil engineers and environmentalists. Producing one tonne of cement requires about 2 tonnes of raw materials and releases 1 tonne of $\mathrm{CO}_{2}$. The global release of $\mathrm{CO}_{2}$ from all sources is estimated at 23 billion tonnes a year and the Portland cement production accounts for about $7 \%$ of total $\mathrm{CO}_{2}$ emissions. The majority of Fly ash produced from thermal power stations in India is disposed in landfills, ponds or rejected in river systems. Therefore, the abundant availability of fly ash worldwide creates opportunity to utilize this by-product of burning coal, as a substitute for OPC to manufacture concrete. In 1978 Davidots introduced geopolymer as new material for cement and describes the composition of mineral binder which is similar to zeolites with amorphous microstructure. Unlike Ordinary Portland Cement, geopolymer do not need calcium-silicate-hydrate (C-S-H) gel for matrix formation and strength, but utilize the polycondensation of silica and alumina precursors to achieve required mechanical strength level. Geo polymer materials are inorganic polymers synthesized by reaction of a strongly alkaline silicate solution and an alumina silicate source. Geo polymer is used as binder to completely replace the ordinary Portland cement in producing Geo polymer concrete (GPC). Geopolymer concrete is made by using $100 \%$ of (fly ash \&GGBS) instead of cement.

Geopolymer concrete is new material to be developed for use in construction work which should be eco-friendly. The properties of Geopolymer concrete are Geopolymer concrete sets at room temperature ,It is non toxic, It has long life, It is impermeable, It is a bad thermal conductor and possess high resistance to inorganic solvents and It gives more strength. Shriram Marathe et.al [6] concluded that Water also play important role in Geopolymer concrete, similar to normal concrete produced using OPC. The amount of water used in Geopolymer concrete is to improve the workability, but it will increase the porosity in Geopolymer concrete due to the evaporation of water during curing process at elevated temperature. The Compressive strength is an essential property for all concrete where it also depends on curing time and curing temperature. When the curing time and temperature increase, the compressive strength also increases, due to a fact that at high temperature the rate of polymerization increases and hence a high strength is observed. In addition, the compressive strength of Geopolymer concrete depends on the content of fly ash fine particles (smaller than 43 $\mu \mathrm{m})$.It has also observed that, as the fineness of fly ash increases, compressive strength also increases. For different fineness of fly-ash different test results are noted from which it is seen that the maximum strength is obtained for fly ash with fineness of $542 \mathrm{~m}^{2} / \mathrm{kg}$. With the addition of slag the curing temperature of geo-polymer concrete get reduce and it can be cured at room temperature also to get good strength. Rohit Zende et.al [7] concluded that with the increase in GGBS content there will be increase in the degree of workability. They also concluded that the concrete with $75 \%$ replacement of slag resulted in maximum Compressive, Split Tensile and Flexural strength values. Robina Kouser Tabassum et.al[8] concluded that the freshly prepared geopoylmer mixes were cohesive and their workability increased with the increase in the ratio of alkaline solution. They also concluded that the strength of geopoylmer concrete can be improved by decreasing the water/ binder and 
aggregate/binder ratios. Compressive strength obtained is in the range of $20.64-60 \mathrm{~N} / \mathrm{mm}^{2}$. And Split tensile strength obtained is in the range 3-4.9 N/mm respectively. Ambily P.S et.al[10] concluded that The mixes had good workability (225-250 mm slump). And also concluded that the mixes had compressive strength in the range of 30 to $44 \mathrm{MPa}$ after 28 days of casting. The objectives of the present work is to finalize the parameters such as Amount of binder used, Molarity of $\mathrm{NaOH}$, Ratio of $\mathrm{Na}_{2} \mathrm{SiO}_{3} / \mathrm{NaOH}$ and Ratio of Liquid to Binder . These finalized parameters are used in investigation of shear behaviour of geopolymer concrete beams.

\subsection{Basalt Aggregate:}

\section{Materials Used}

Basalt aggregate of two fractions i.e. $20 \mathrm{~mm}$ and $12.5 \mathrm{~mm}$ were used in the present work with specific gravity of 2.81, Finess modulus of aggregate was 8.26 , Bulk density in the loose and compacted condition was 1.49 and $1.74 \mathrm{~g} / \mathrm{cc}$, aggregates had a crushing value of $15.29 \%$, Impact Value of $13.94 \%$ and water absorption of $2.34 \%$. The Sieve analysis test was carried to determine the grading of the aggregate and it was found that the aggregates were nearly graded .

\subsection{Fine Aggregate:}

Good quality zone-II fine aggregate locally available was used having Specific gravity of 2.74, Finess Modulus of 3.60, Water Absorption of $0.61 \%$ and having Loose and Compacted Bulk Density of $1.51 \mathrm{~g} / \mathrm{cc}$ and $1.69 \mathrm{~g} / \mathrm{cc}$ respectively. The fine aggregate conforming to IS:383-1970[8] was used.

\subsection{Fly Ash}

In this experimental work, low calcium, class $\mathrm{F}$ fly ash from the Raichur thermal power station, Karnataka state was used. The Chemical Composition and Physical Properties of fly ash as supplied by supplier are presented in Table 1 and Table 2 respectively.

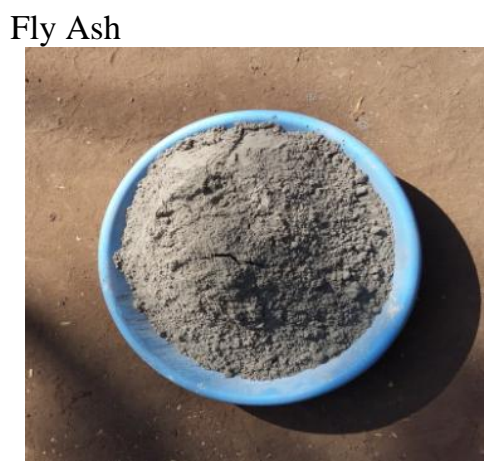

Table 1: Chemical Composition of Fly Ash

Table 2:Physical Properties of Fly Ash

\begin{tabular}{|c|c|c|c|}
\hline $\begin{array}{c}\text { S1 } \\
\text {. }\end{array}$ & $\begin{array}{c}\text { Sieve Size in } \\
\text { Micron }\end{array}$ & Weight Retained in Grams & \% Passing \\
\hline 1. & 90 & 95 & $92 \%$ \\
\hline 2 & 75 & 122 & $83 \%$ \\
\hline 3 & 45 & 704 & $62 \%$ \\
\hline 4 & Specific Gravity & \multicolumn{2}{|c|}{1.8} \\
\hline 5 & $\begin{array}{c}\text { Finess (Blains Air } \\
\text { Permiability }\end{array}$ & \multicolumn{2}{|c|}{$519 \mathrm{~m}^{2} / \mathrm{kg}$} \\
\hline
\end{tabular}

\subsection{GGBS (Ground Granulated Blast Furnace Slag)}

In this experimental work, GGBS from the JSW Steel Ltd of Bellary, Karnataka state was used. The chemical composition of GGBS as supplied by supplier is presented in Table 3.

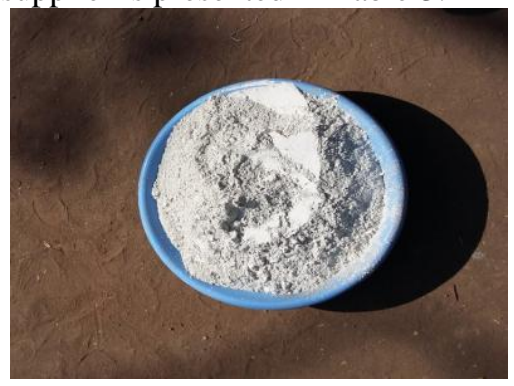

GGBS 
Table 3: Chemical Composition of GGBS

\begin{tabular}{|c|c|c|c|}
\hline $\begin{array}{c}\text { S1 } \\
\text { o. }\end{array}$ & $\begin{array}{l}\text { Characteristics Chemical } \\
\text { Requirements }\end{array}$ & $\begin{array}{c}\text { Requirement as per } \\
\text { BS:6699 }\end{array}$ & Test Result \\
\hline 1. & Fineness( $\left.{ }^{2} / \mathrm{Kg}\right)$ & $275(\mathrm{Min})$ & 404 \\
\hline 2 & Specific Gravity & & 2.88 \\
\hline 3 & 45 Micron (Residue)(\%) & & 6.60 \\
\hline 4 & Insoluble Residue(\%) & $1.5(\mathrm{Max})$ & 0.40 \\
\hline 5 & Magnesia Content $(\%)$ & $14.0(\mathrm{Max})$ & 7.90 \\
\hline 6 & Sulphide Sulphur(\%) & $2.00(\mathrm{Max})$ & 0.55 \\
\hline 7 & Sulphite Content $(\%)$ & $2.50(\mathrm{Max})$ & 0.33 \\
\hline 8 & Loss on Ignition(\%) & $3.00(\mathrm{Max})$ & 0.33 \\
\hline 9 & Manganese content $(\%)$ & $2.00(\mathrm{Max})$ & 0.12 \\
\hline 10 & Chloride Content $(\%)$ & $0.10(\mathrm{Max})$ & 0.007 \\
\hline 11 & Glass Content $(\%)$ & $67(\mathrm{Min})$ & 91 \\
\hline 12 & Moisture Content $(\%)$ & $1.00(\mathrm{Max})$ & 0.12 \\
\hline 13 & Chemical Modulus & & 77.25 \\
A & Cao +Mgo+SiO2 & $66.66(\mathrm{Min})$ & 1.38 \\
$\mathrm{~B}$ & $($ Cao + Mgo)/SiO2 & $>1.0$ & 1.13 \\
C & Cao/SiO2 & $<1.40$ & \\
\hline
\end{tabular}

\subsection{Alkaline liquids (Sodium Hydroxide \& Sodium Silicate):}

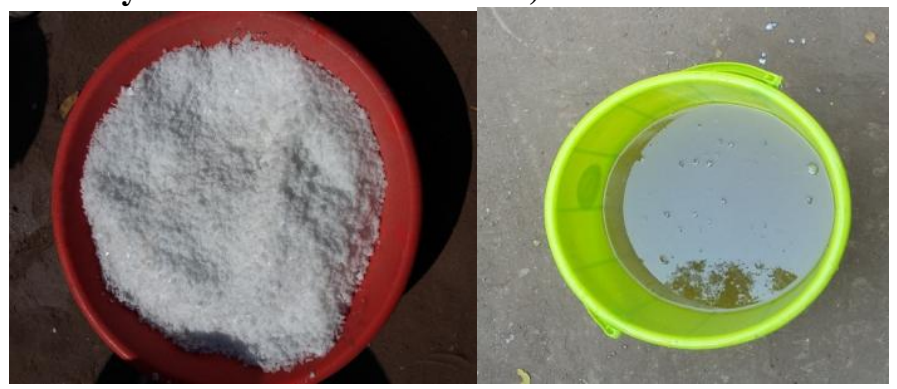

\section{Sodium Hydroxide Flakes Sodium Silicate Solution}

2.5.1 Sodium Hydroxide: The Sodium Hydroxide $(\mathrm{NaOH})$ is commonly called as caustic soda and it is available in flakes or pellets form with 97\%-98\% Purity. It was purchased from suppliers in bulk. According to the requirement concentration the $\mathrm{NaOH}$ solids were dissolved in water to make the solution.

2.5.2 Sodium Silicate: The Sodium Silicate Solution was purchased from the local supplier in bulk, and it is commonly called as liquid glass. The Chemical composition of sodium silicate used for this experimental work was $\mathrm{Na}_{2} \mathrm{O}=13.7 \%, \mathrm{SiO}_{2}=29.4 \%$, and water $=55.9 \%$ by mass.

\subsection{Casting:}

\section{Methodology}

Cube specimen of size $15 \mathrm{~cm} \times 15 \mathrm{~cm} \times 15 \mathrm{~cm}$ were cast using the finalized mix proportion of Geopolymer concrete for compressive strength test as per IS:516-1959[10].

\subsection{Curing:}

The cubes were demoulded after 24 hours of casting. The cubes of Geopolymer concrete were kept for curing Under Ambient Curing at laboratory temperature $27 \pm 2^{\circ}$ C.for 1,3 and 7 Days. After curing cubes were tested for compressive strength and details of testing procedure is presented in the following section.

\subsection{Testing:}

\subsubsection{Compressive strength:}

The compressive strength test was carried out using IS: 516-1959 [10] code book. At the end of curing period, i.e. 1 days, 3 days and 7 days for Geopolymer Cubes and for a period of 28 days for Geopolymer Concrete cubes. compressive strength test was conducted.. Cube specimens were tested for compressive strength under UTM as per IS 9013 (1978). Specimens were placed under in a direction perpendicular to the direction in which they were cast. Rate of loading is maintained at $140 \mathrm{~kg} / \mathrm{sq} \mathrm{cm} / \mathrm{min}$. 


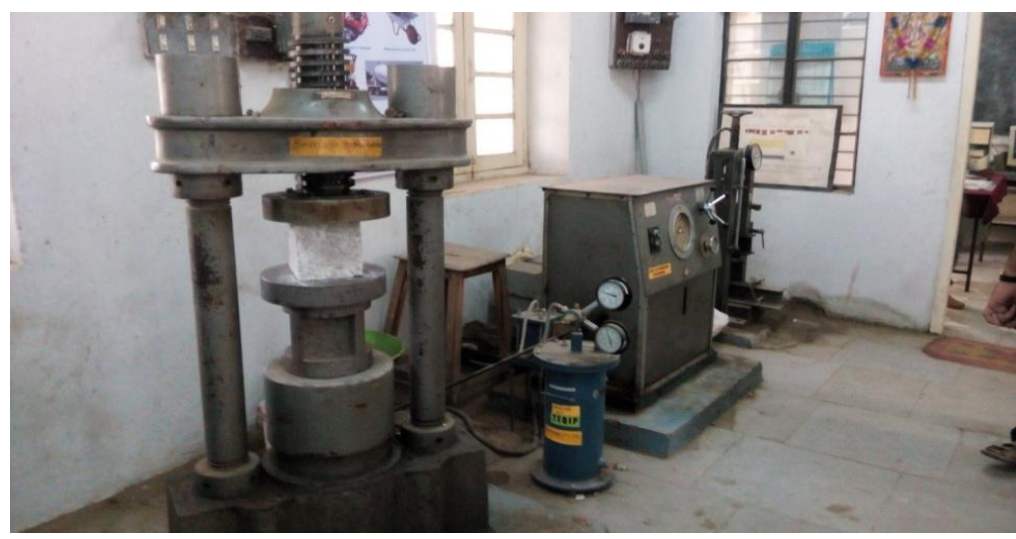

Universal Testing Machine

\section{Determinination Of Geopolymer Concrete Parametres}

This Chapter presents the details of mix design, casting and Testing of Geopolymer concrete specimens. In order to simplify the development process the compressive strength was selected as the benchmark parameter. . The mix proportions for Geopolymer concrete are given in the following Tables.

The following Parameter had to be finalized in order to prepare the Geopolymer Concrete

- The Percentage of Binders used (Fly Ash+ GGBS)

- Molarity of $\mathrm{NaOH}$ Considered (8M-16M)

- Ratio of $\mathrm{Na}_{2} \mathrm{SiO}_{3} / \mathrm{NaOH}$

- Ratio of Liquid/Binder

Table 4. Mix Proportion of Geopolymer Concrete for determining Percentage of Binder

\begin{tabular}{|c|c|c|c|c|c|c|c|c|}
\hline \multirow{2}{*}{$\begin{array}{l}\text { S1 } \\
\text { No. }\end{array}$} & \multirow{2}{*}{$\begin{array}{l}\text { GPC(Fly Ash } \\
\text { GGBS) }\end{array}$} & \multicolumn{2}{|c|}{ Binder in $\mathrm{Kg} / \mathrm{m}^{3}$} & \multicolumn{2}{|c|}{ Aggregate in $\mathrm{Kg} / \mathrm{m}^{3}$} & \multirow[t]{2}{*}{ Sand in $\mathrm{Kg} / \mathrm{m}^{3}$} & \multirow[t]{2}{*}{$\mathrm{NaOH}$ in $\mathrm{Kg} / \mathrm{m}^{3}$} & \multirow[t]{2}{*}{$\mathrm{Na}_{2} \mathrm{SiO}_{3}$ in $\mathrm{Kg} / \mathrm{m}^{3}$} \\
\hline & & Fly Ash & GGBS & $12.5 \mathrm{~mm}$ & $20 \mathrm{~mm}$ & & & \\
\hline \multirow[t]{5}{*}{1} & G1(20:80) & 73.6 & 294.4 & 517.44 & 776.16 & 554.4 & 52.57 & 131.43 \\
\hline & G2(40:60) & 147.2 & 220.8 & 517.44 & 776.16 & 554.4 & 52.57 & 131.43 \\
\hline & G3(50:50) & 184 & 184 & 517.44 & 776.16 & 554.4 & 52.57 & 131.43 \\
\hline & G4(60:40) & 220.8 & 147.2 & 517.44 & 776.16 & 554.4 & 52.57 & 131.43 \\
\hline & G5(80:20) & 294.4 & 73.6 & 517.44 & 776.16 & 554.4 & 52.57 & 131.43 \\
\hline
\end{tabular}

4.1 Trial casting of Geopolymer Concrete to determine Binder Content:

The various parameters considered for trial casting are $\mathrm{L} / \mathrm{B}$ Ratio $=0.5$, Molarity of $\mathrm{NaOH}=8 \mathrm{M}$ and $\mathrm{NaSiO}_{3} / \mathrm{NaOH}=2.5$. Trial castings were carried out for the different combinations of Binder (Fly Ash + GGBS) to prepare the Geopolymer Concrete. Cubes were cured under ambient curing for 1, 3 and 7 days. Compressive strength of cubes were determined and results are presented in the Table 5.

Table 5. Trial Casting Results for Geopolymer Concrete for Binder Content

\begin{tabular}{|c|c|c|c|c|c|c|}
\hline \multirow{3}{*}{ S1 No. } & GPC & \multicolumn{3}{|c|}{ Binder } & \multicolumn{2}{c|}{$\begin{array}{c}\text { Compressive Strength in N/mm2 } \\
\text { [ Ambient Curing] }\end{array}$} \\
\cline { 3 - 7 } & & Fly Ash & GGBS & 1 Day & 3 Day & 7 Day \\
\hline \multirow{3}{*}{1} & G1 & 20 & 80 & 27.3 & 46.5 & 67.1 \\
\cline { 2 - 7 } & G2 & 40 & 60 & 24 & 40 & 60 \\
\cline { 2 - 7 } & G3 & 50 & 50 & 21 & 37 & 54 \\
\cline { 2 - 7 } & G4 & 60 & 40 & 20 & 26 & 48 \\
\cline { 2 - 7 } & G5 & 80 & 20 & 15.7 & 26 & 31 \\
\hline
\end{tabular}

Based on the results of trial castings presented in Table no 5. It is observed that for G3 Mix of Geopolymer Concrete Containing Binder Content(Fly ash : GGBS) of (40:60) resulted in good compressive strength. Therefore binder content (Fly ash :GGBS) of (40:60) is considered for final casting.

Table 6. Mix Proportion of Geopolymer Concrete for determining Molarity of $\mathrm{NaOH}$

\begin{tabular}{|c|c|c|c|c|c|c|c|c|}
\hline \multirow{2}{*}{$\begin{array}{l}\text { Sl } \\
\text { No. }\end{array}$} & \multirow{2}{*}{$\begin{array}{c}\text { GPC(Molarity of } \\
\mathrm{NaOH})\end{array}$} & \multicolumn{2}{|c|}{ Binder in $\mathrm{Kg} / \mathrm{m}^{3}$} & \multicolumn{2}{|c|}{ Aggregate in $\mathrm{Kg} / \mathrm{m}^{3}$} & \multirow{2}{*}{$\begin{array}{l}\text { Sand in } \\
\mathrm{Kg} / \mathrm{m}^{3}\end{array}$} & \multirow{2}{*}{$\begin{array}{l}\mathrm{NaOH} \text { in } \\
\mathrm{Kg} / \mathrm{m}^{3}\end{array}$} & \multirow{2}{*}{$\begin{array}{c}\mathrm{Na}_{2} \mathrm{SiO}_{3} \text { in } \\
\mathrm{Kg} / \mathrm{m}^{3}\end{array}$} \\
\hline & & Fly Ash & GGBS & $12.5 \mathrm{~mm}$ & $20 \mathrm{~mm}$ & & & \\
\hline \multirow[t]{3}{*}{1} & $\mathrm{G} 1(8 \mathrm{M})$ & 147.2 & 220.8 & 517.44 & 776.16 & 554.4 & 52.57 & 131.43 \\
\hline & G2(10M) & 147.2 & 220.8 & 517.44 & 776.16 & 554.4 & 52.57 & 131.43 \\
\hline & $\mathrm{G} 3(12 \mathrm{M})$ & 147.2 & 220.8 & 517.44 & 776.16 & 554.4 & 52.57 & 131.43 \\
\hline
\end{tabular}




\subsection{Trial casting of Geopolymer Concrete to determine Molarity of $\mathrm{NaOH}$}

The various parameters considered for trial casting are Binder(Fly Ash: GGBS) $=(40: 60), \mathrm{L} / \mathrm{B}$ Ratio= $0.5, \quad \mathrm{NaSiO}_{3} / \mathrm{NaOH}=2.5$. Trial castings were carried out for the different Molarity of $\mathrm{NaOH}$ to prepare the Geopolymer Concrete .Cubes were cured under ambient curing for 1, 3 and 7 days. Compressive strength of cubes were determined and results are presented in the Table 7.

Table 7. Trial Casting Results for Geopolymer Concrete for Binder Content

\begin{tabular}{|c|c|c|c|c|c|}
\hline S1 No. & GPC & Molarity of $\mathrm{NaOH}$ & \multicolumn{3}{|c|}{$\begin{array}{c}\text { Compressive Strength in N/mm2 } \\
\text { [ Ambient Curing] }\end{array}$} \\
\cline { 4 - 6 } & & & 1 Day & 3 Day & 7 Day \\
\hline \multirow{2}{*}{1} & G1 & $8 \mathrm{M}$ & 24 & 40 & 60 \\
\cline { 2 - 6 } & G2 & $10 \mathrm{M}$ & 24.7 & 41 & 62 \\
\cline { 2 - 6 } & G3 & $12 \mathrm{M}$ & 23 & 39 & 57 \\
\hline
\end{tabular}

Based on the results of trial castings presented in Table no 7. It is observed that for G1 Mix of Geopolymer Concrete Containing 8M Molarity of $\mathrm{NaOH}$ has resulted in good compressive strength . Therefore $8 \mathrm{M}$ Molarity of $\mathrm{NaOH}$ is considered for final casting.

Table 8. Mix Proportion of Geopolymer Concrete for determining Ratio of $\mathrm{Na}_{2} \mathrm{SiO}_{3} / \mathrm{NaOH}$

\begin{tabular}{|c|c|c|c|c|c|c|c|c|}
\hline \multirow{2}{*}{$\begin{array}{r}\text { Sl } \\
\text { No. }\end{array}$} & \multirow{2}{*}{$\begin{array}{l}\mathrm{GPC}( \\
\left.\mathrm{Na}_{2} \mathrm{SiO}_{3} / \mathrm{NaOH}\right)\end{array}$} & \multicolumn{2}{|c|}{ Binder in $\mathrm{Kg} / \mathrm{m}^{3}$} & \multicolumn{2}{|c|}{ Aggregate in $\mathrm{Kg} / \mathrm{m}^{3}$} & \multirow{2}{*}{$\begin{array}{l}\text { Sand in } \\
\mathrm{Kg} / \mathrm{m}^{3}\end{array}$} & \multirow{2}{*}{$\begin{array}{c}\mathrm{NaOH} \text { in } \\
\mathrm{Kg} / \mathrm{m}^{3}\end{array}$} & \multirow{2}{*}{$\begin{array}{c}\mathrm{Na}_{2} \mathrm{SiO}_{3} \text { in } \\
\mathrm{Kg} / \mathrm{m}^{3}\end{array}$} \\
\hline & & Fly Ash & GGBS & $12.5 \mathrm{~mm}$ & $20 \mathrm{~mm}$ & & & \\
\hline \multirow[t]{3}{*}{1} & G1(1.5) & 147.2 & 220.8 & 517.44 & 776.16 & 554.4 & 73.6 & 110.4 \\
\hline & $\mathrm{G} 2(2)$ & 147.2 & 220.8 & 517.44 & 776.16 & 554.4 & 61.3 & 122.6 \\
\hline & G3(2.5) & 147.2 & 220.8 & 517.44 & 776.16 & 554.4 & 52.57 & 131.43 \\
\hline
\end{tabular}

\subsection{Trial casting of Geopolymer Concrete to determine Ratio of $\mathrm{Na}_{2} \mathrm{SiO}_{3} / \mathrm{NaOH}$ :}

The various parameters considered for trial casting are Binder(Fly Ash: GGBS $)=(40: 60), \mathrm{L} / \mathrm{B}$ Ratio $=0.5$, Molarity of $\mathrm{NaOH}=8 \mathrm{M}$. Trial castings were carried out for the different Ratio of $\mathrm{NaSiO}_{3} / \mathrm{NaOH}$ to prepare the Geopolymer Concrete. Cubes were cured under ambient curing for 1, 3 and 7 days. Compressive strength of cubes were determined and results are presented in the Table 9.

Table 9. Trial Casting Results for Geopolymer Concrete for Ratio of $\mathrm{Na}_{2} \mathrm{SiO}_{3} / \mathrm{NaOH}$

\begin{tabular}{|c|c|c|c|c|c|}
\hline S1 No. & GPC & \multirow{2}{*}{$\begin{array}{c}\text { Ratio of } \\
\mathrm{Na}_{2} \mathrm{SiO}_{3} / \mathrm{NaOH}\end{array}$} & \multicolumn{3}{|c|}{$\begin{array}{c}\text { Compressive Strength in N/mm2 } \\
\text { [ Ambient Curing] }\end{array}$} \\
\cline { 4 - 6 } & & & 1 Day & 3 Day & 7 Day \\
\hline \multirow{2}{*}{1} & $\mathrm{G} 1$ & 1.5 & 27 & 44 & 64 \\
\cline { 2 - 6 } & $\mathrm{G} 2$ & 2 & 25 & 42 & 61 \\
\cline { 2 - 6 } & $\mathrm{G} 3$ & 2.5 & 24 & 40 & 60 \\
\hline
\end{tabular}

Based on the results of trial castings presented in Table no 9. It is observed that for G1 Mix of Geopolymer Concrete Containing Ratio of $\mathrm{NaSiO}_{3} / \mathrm{NaOH}$ of 1.5 has resulted in good compressive strength .Therefore Ratio of $\mathrm{NaSiO}_{3} / \mathrm{NaOH}$ of 1.5 was considered for final casting.

Table 10. Mix Proportion of Geopolymer Concrete for determining Liquid to Binder ratio

\begin{tabular}{|c|c|c|c|c|c|c|c|c|}
\hline \multirow{2}{*}{$\begin{array}{l}\text { S1 } \\
\text { No. }\end{array}$} & \multirow{2}{*}{$\begin{array}{l}\text { GPC( Liquid to } \\
\text { Binder ) }\end{array}$} & \multicolumn{2}{|c|}{ Binder in $\mathrm{Kg} / \mathrm{m}^{3}$} & \multicolumn{2}{|c|}{ Aggregate in $\mathrm{Kg} / \mathrm{m}^{3}$} & \multirow{2}{*}{$\begin{array}{l}\text { Sand in } \\
\mathrm{Kg} / \mathrm{m}^{3}\end{array}$} & \multirow{2}{*}{$\begin{array}{l}\mathrm{NaOH} \text { in } \\
\mathrm{Kg} / \mathrm{m}^{3}\end{array}$} & \multirow{2}{*}{$\begin{array}{c}\mathrm{Na}_{2} \mathrm{SiO}_{3} \text { in } \\
\mathrm{Kg} / \mathrm{m}^{3}\end{array}$} \\
\hline & & Fly Ash & GGBS & $12.5 \mathrm{~mm}$ & $20 \mathrm{~mm}$ & & & \\
\hline \multirow[t]{3}{*}{1} & G1(0.45) & 152.4 & 228.6 & 517.44 & 776.16 & 554.4 & 68.4 & 102.6 \\
\hline & G2(0.5) & 147.2 & 220.8 & 517.44 & 776.16 & 554.4 & 73.6 & 110.4 \\
\hline & G3(0.55) & 142.4 & 213.6 & 517.44 & 776.16 & 554.4 & 78.4 & 117.6 \\
\hline
\end{tabular}

\subsection{Trial casting of Geopolymer Concrete determine Liquid to Binder ratio :}

The various parameters considered for trial casting are Binder(Fly Ash: GGBS $)=(40: 60)$, Molarity of $\mathrm{NaOH}=8 \mathrm{M}, \quad \mathrm{NaSiO}_{3} / \mathrm{NaOH}=1.5$. Trial castings were carried out for the different Ratio of Liquid to Binder to prepare the Geopolymer Concrete. Cubes were cured under ambient curing for 1, 3 and 7 days. Compressive strength of cubes were determined and results are presented in the Table 11.

Table 11. Trial Casting Results for Geopolymer Concrete for determining Ratio of Liquid to Binder

\begin{tabular}{|c|c|c|c|c|c|}
\hline \multirow{3}{*}{ S1 No. } & GPC & $\begin{array}{c}\text { Ratio of Liquid to } \\
\text { Binder }\end{array}$ & \multicolumn{3}{|c|}{$\begin{array}{c}\text { Compressive Strength in N/mm2 } \\
\text { [ Ambient Curing] }\end{array}$} \\
\cline { 4 - 6 } & & & 1 Day & 3 Day & 7 Day \\
\hline \multirow{2}{*}{1} & G1 & 0.45 & 23 & 37 & 54 \\
\cline { 2 - 6 } & G2 & 0.50 & 24 & 40 & 60 \\
\cline { 2 - 6 } & G3 & 0.55 & 21 & 30 & 49 \\
\hline
\end{tabular}


Based on the results of trial castings presented in Table no 11. It is observed that for G1 Mix of Geopolymer Concrete Containing Ratio of Liquid to Binder of 0.5 has resulted in good compressive strength .Therefore Liquid to binder ratio of 0.5 was considered for final casting.

The Finalized parameter obtained for the Geopolymer Concrete is as follows

- $\quad$ Binder(Fly Ash: GGBS $)=(40: 60)$

- Molarity of $\mathrm{NaOH}=8 \mathrm{M}$

- $\quad$ Ratio of $\mathrm{Na}_{2} \mathrm{SiO}_{3} / \mathrm{NaOH}=1.5$

- $\quad$ Ratio of Liquid/Binder $=0.5$

Table 12. Final Casting Results for Geopolymer Concrete

\begin{tabular}{|c|c|c|c|c|}
\hline S1 No. & \multirow{2}{*}{ GPC } & \multicolumn{3}{|c|}{$\begin{array}{l}\text { Compressive Strength in N/mm2 } \\
\text { [ Ambient Curing] }\end{array}$} \\
\cline { 3 - 5 } & & 1 Day & 3 Day & 7 Day \\
\cline { 2 - 5 } & G1 & 24 & 40 & 60 \\
\hline
\end{tabular}

The various parameters considered for final casting are Binder (Fly Ash: GGBS) $=(40: 60)$, Molarity of $\mathrm{NaOH}=8 \mathrm{M}, \quad \mathrm{NaSiO}_{3} / \mathrm{NaOH}=1.5$. and Liquid to Binder Ratio of 0.5 Final castings were carried out to prepare the Geopolymer Concrete. Cubes were cured under ambient curing for 1, 3 and 7 days. Compressive strength of cubes were determined and results are presented in the Table 12 .

\section{Conclusion}

Following conclusions are drawn from this investigation.

- Addition of GGBS in Geopolymer concrete enhances the polymerization at Ambient Temperature only and results in good compressive strength.

- The Mix containing Binder of (Fly Ash: GGBS) of (40:60) resulted a higher strength.

- In the present study it is observed that with increase in the Molarity $(8 \mathrm{M}, 10 \mathrm{M} \& 12 \mathrm{M})$ of $\mathrm{NaOH}$ there is marginal increase in the strength was observed.

- It is observed that Ratio of $\mathrm{Na}_{2} \mathrm{SiO}_{3} / \mathrm{NaOH}$ of 1.5 resulted in good compressive strength as compared to the other ratio of $\mathrm{Na}_{2} \mathrm{SiO}_{3} / \mathrm{NaOH}$ of 2 and 2.5 .

- It is observed that Ratio of Liquid/Binder of 0.5 resulted in higher compressive strength.

\section{References}

[1] C.K.Madheswaran, P S Ambily, "Experimental Studon Behaviour of Reinforced Geopolymer Concrete Beams Subjected Monotoinc Static Loading" IJIRSET Journal of Engineering, ISSN:2319-8753,Vol3, Issue7, July2014

[2] Ambily .P.S, Madheswaran.C.K, "Experimental and analytical investigations on shear behaviour of reinforced Geopolymer concrete beams" International Journal of Civil and Structural Engineering ISSN 0976-4399, Volume, No2, 2011.

[3] Ganesh Kumar ,Dr MT Abdul Aleem, S Dinesh, “ Application of Geopolymer Concrete”, IRJET Journal of Enginerring ISSN:2395-0056 Volume:02 Issue09, Dec-2015

[4] R. Mourougane,, C.G.Puttappa,C.Sashidhar and K.U.Muthu,"Shear Behaviour of High Strength GPC/TVC Beams",AARCV 2012),21-23 June 2012,Paper ID SAM16, VOl 1

[5] Ginghis B. MAranan "Comparasion of the Shear Behaviour of Geopolymer Concrete beams with GFRP and steel Transverse Reinforcements "FRPRCS-12), Joint Conference,14-16 December 2015.

[6] Shriram Marathe "A Review on strength and durability studies on Geopolymer Concrete",ISSN:2319-8753,IJIRSET Vol.5,Special Issue 9, May 2016-11-23

[7] Rohit Zende "Study on Fly Ash and GGBS based Geopolymer Concrete Under Ambient Curing",IJTIR(ISSN-2349-51620,July 2015 Volume2, Issue 7

[8] Robina Kouser Tabassum “ A Brief Review on Geopolymer Concrete “ IJARET, ISSN:2394-2975, Vol.2, Issue 3 (July-Sep 2015)

[9] Sarker,P.K "Structural Behaviour and Design of Geopolymer Concrete Members",CED2015, ISSN 1410-9530, Vol.17, No3, December 2015 Special Edition,133-139.

[10] Ambily P.S, Madheswaran C.K, "Experimental Studies on shear Behaviour of Reinforced Geopolymer Concrete thin webbed TBeams with and without fibres",IJCASE, ISSN 0976-4399 Vol.3, NO.1,201

[11] ACI Committee 232(2004). "Use of Fly Ash in Concrete". Farmington Hills, Michingan, USA, American Concrete Instite:41.

[12] P.Vignesh,K.Vivek, "An Experimental Investigation on strength parameters of fly ash Based Geopolymer Concrete with GGBS, IJRET, ISSN:2395-0056 Vol 2 Issue 2 May 2015

[13] G. Lavanya, J.Jegan, "Structural Behaviour of High calcium fly ash geopolymer concrete beam",IJAFRD, ISSN :2348-4470. Vol 3. March-2016

[14] M.Sheik Mohamed, V.Kalpana,'Review on shearing Restance of Reinforced Concrete Beam without Shear Reinforcement, IRJET,ISSN:2395-0056,Vol3 Issue 5 ,May2016

[15] MAhdi Arezoumandi,"An Experimental study on shear study of reinforced concrete beams with $100 \%$ recycled concrete aggregate,'Construction and Building Material

[16] IS:12269-1987:Specifications for 53 Grade Ordinary Portland Cement

[17] IS:383-1970, Specifications for coarse and fine aggregate from natural sources for concrete. Bureau of Indian Standards, New Delhi, India.

[18] IS:10262-1982,Recommended guidelines for concrete mix design, Bureau of Indian Standards, New Delhi, India.

[19] IS:456-2000, Indian Standard code for plain and reinforced concrete, Bureau of Indian Standards, New Delhi, India

[20] IS:516-1959, Indian Standard code of practice methods of test for strength of concrete, Bureau of Indian Standards, New Delhi. 